\title{
The Substitution of Wheat Flour with Mixed-Cassava (Manihot utilissima) and Red Beans-Flour (Phaseolus vulgaris L.) Toward The Characteristics of Instant Noodles
}

\author{
Novelina $^{\# 1}$, Neswati ${ }^{\#}$ and Anggun Fitria ${ }^{\#}$ \\ \# Faculty of Agricultural Technology, Andalas University, Limau Manis Padang Indonesia \\ E-mail:novelinasutanto@yahoo.com
}

\begin{abstract}
Instant noodles are defined as dry food products made of wheat flour with the addition of other foodstuffs. Cassava flour can be used together with wheat flour as a basic ingredient for the noodles, in order to reduce the use of wheat flour. The purpose of this study was to determine the degree of substitution of cassava flour to the wheat flour which was enriched with red bean flour toward the quality of instant noodles that had been produced. The treatment in this study was done by mixing $70 \%$ of wheat flour with $30 \%$ of cassava and red beans flour mixture at various levels. The observations was carried out on raw materials and the instant noodle products, including moisture content, ash content, protein content, fat content and carbohydrate content as well as by different organoleptic test of the flavour, aroma, texture and colour. The results showed that the noodles product that was the most qualified and preferred was the product with the treatment $D$ (a mixture of $70 \%$ of wheat flour; $20 \%$ of cassava flour and $10 \%$ of red bean flour), with the test results of $2.24 \%$ of moisture content, $1.07 \%$ of ash content, $9.36 \%$ of protein content, $17.77 \%$ of fat content, carbohydrate content by different of $69.95 \%$, and $71.53 \%$ of yield.
\end{abstract}

Keywords-Cassava, Kidney Beans, Instant Noodles

\section{INTRODUCTION}

Cassava is the third of the most important food crops in Indonesia after rice and maize. The advantages of using cassava as the feedstock of noodle product is no need for the addition of and chewy-texture developers. The disadvantage of cassava as a food ingredient is the low of protein content. The protein content had been decreased approximately $1 \%$ in every increase of $10 \%$ of cassava flour substitution, therefore the addition of protein source was needed as it was for the use of cassava flour as a wheat substituents. Protein can come from animals or vegetables. One of the good sources of vegetable protein with relatively low prices is red bean [1].

Red beans have a relatively high protein content. Protein content in 100 grams of dried red bean which has been firstly boiled provides $19-21 \%$ of protein. Red beans are a source of complex carbohydrates and also contributes minerals, vitamin B, (especially folic acid and vitamin B1), calcium, phosphorus, iron, and fiber. In addition, Red beans are very low of fat, natrium, cholesterol and sodium [2].

Based on the description above, this research was conducted in order to determine the level of substitution of cassava flour to wheat flour that was enriched with kidney bean flour on the quality of the instant noodles in accordance with SNI 01-3551-2000 [3].

\section{METHODOLOGY}

The research design that was used in this study was a Completely Randomized Design (CRD), consisting of five treatments and three replications. The data was analyzed by using analysis of variance, if it was significantly different then it would be followed by Duncan's New Multiple Range Test (DNMRT) at the level of 5\%. The treatments were:
A (70 g wheat flour: $30 \mathrm{~g}$ cassava flour)
B (70 g wheat flour: $24 \mathrm{~g}$ cassava flour + red bean $6 \mathrm{~g}$ )
$\mathrm{C}$ (70 g wheat flour: $22 \mathrm{~g}$ cassava flour + red bean $8 \mathrm{~g}$ )
$\mathrm{D}$ (70 g wheat flour: $20 \mathrm{~g}$ cassava flour + red bean $10 \mathrm{~g}$ )
$\mathrm{E}$ (70 g wheat flour: $18 \mathrm{~g}$ cassava flour + red bean $12 \mathrm{~g}$ )

Observations were made of the raw material (cassava flour and kidney bean flour) and instant noodles. The observation of the raw materials included the analysis of water content, ash content, protein content, fat content and by different carbohydrate content. While the observations made on the analysis of dried noodles was on the moisture 
content, ash content, protein content, fat content, by different carbohydrates levels, yield and organoleptic observations that was covering the taste, aroma, texture and color.All the chemical analyzes were carried out by the procedure of SNI 01-3551-2000.

\section{A. The Making of Cassava Flour (Suprapti modified) [4]}

Select the cassava that is no more than one week after harvest \{ because if it is more than one week, there will be a lot of green stripes to black-brown on the cassava which contains HCN (hydrogen cyanide) that is toxic .Peel the cassava's skin by using a knife.Wash the cassava, then grate it by using grater that is accommodated in water, then drain it.Dry the sliced-cassavas in the sun untill it sounds "crack" when it is broken by hand, with water content $( \pm 8 \%)$.Mill the sliced-cassavas by using a blender.Sieve the milledcassava by using a sieve with a mesh size of 60 .

\section{B. The Making of Red Bean Flour (Intania modified) [5]}

Sort and wash the kidney beans. Then soak the beans for 1 night (eliminating anti-nutritional substances contained in nuts). Next, boil the beans for 30 minutes, after that steam and drain them ready for \pm 15 minutes.Do the seed exfoliation and sun dry the beans until they have $8 \%$ of water content. Grind the beans into powder and then sieve them by using a 60 mesh sieve.

\section{The Making of Instant Noodles (Astawan modified) [6]}

Dissolve $1 \mathrm{~g}$ of salt isin $60 \mathrm{ml}$ of water. Mix all the flour in accordance with the treatment and add salted-water, then stir it until the dough is evenly distributed. Put the mixture into the plate on ampia (pasta or noodle maker) to make the pasta sheets with a thickness of $1.5 \mathrm{~mm}$. The sheet of dough that has been formed is passed to the noodles maker tool, thus it is obtained with a thickness of $1.5 \mathrm{~mm}$. The strands of noodle that is formed will have the cooking process by steaming at a temperature of $100^{\circ} \mathrm{C}$ for 10 minutes. Fry the noodles by using cooking oil with a temperature of $150^{\circ} \mathrm{C}$ for 2 minutes by using a regular frying cauldron. The noodles that have been fried are cooled, packaged and ready to be analyzed.

\section{RESULTS AND DISCUSSION}

\section{A. Raw materials}

The raw materials used were fresh cassava and kidney beans that were further processed into cassava flour and kidney bean flour. The cassava flour and kidney beans that were used to manufacture dry noodles were analyzed to determine proximate nutritional composition. The results of chemical analysis on cassava flour can be seen in Table 1.

TABLE I

Chemical Characteristics of CASSAVA Flour AND RED BEANS Flour

\begin{tabular}{|l|c|c|}
\hline Component & Cassava Flour & Red Beans Flour \\
\hline Water (\%) & 11,28 & 8,88 \\
\hline Ash (\%) & $\mathrm{I}, 46$ & 3,84 \\
\hline Protein (\%) & 1,52 & 21,25 \\
\hline Fat (\%) & 0,47 & 1,79 \\
\hline Carbohydrate (\%) & 85,27 & 64,24 \\
\hline
\end{tabular}

The results of the analysis conducted on the water content of cassava flour and red beans flour was under requirement of ISO 3751: 2006, which is a maximum of $14.5 \%$. The water content greatly affects the shelf life of the flour, the higher the water content of the flour, the shorter the shelf life.

\section{B. Instant Noodles}

Chemical analysis is a parameter that determines the quality of instant noodles. The nature and the characteristics of the flour mixture will relate to the quality of the resulting noodles. The chemical analysis of instant noodles can be seen in Table 2.

\section{Moisture Content}

In Table 2, it can be seen that the water content of the resulting instant noodles ranged from 1.95 to $3.52 \%$. The higher the addition of red beans flour, the lower the water content of the product.This was because the water content of cassava flour was higher than the red beans flour, and the decrease in the amount of cassava flour meant a decrease in starch content, so the water absorption ability became lower which caused the water content of resulting instant noodles was also lower.In the process of cooking the starch, the starch will absorb the water. The higher the starch content, the greater water absorption happens. According Kusnandar (2010) [7], when starch is heated, the water will replace the intermolecular amylose hydrogen bonding or amylopectin by forming hydrogen bonds with water or water-amyloseamylopectin. Based on SNI 01-3551-2000 [4] quality standards, instant noodles mixed with frying methods have a maximum moisture content of $10 \%$.

\section{Ash Content}

The ash content in instant noodles increased with the addition of kidney beans flour.The increasing levels of ash was caused by the mineral content of red beans flour which played a major role in the increase of ash content of instant noodles. The ash content of the red beans flour used in this study was $3.84 \%$.Mineral elements are also known as organic matter or ash content.In combustion, the organic materials are burnt but not inorganic substances; therefore it is called ash [9].

\section{E. Protein Content}

Based on Table 2, the higher the addition of the red beans flour, the noodles protein levels will also increase. From the results obtained of protein content, the treatments which met the minimum of SNI 01-3551-2000 standard of $8 \%$ of protein content were treatment C, D and E. According to Astawan (2009) [8], dried red beans have very high protein content, which reach to $22.3 \mathrm{~g}$ per $100 \mathrm{~g}$ of the material.The highest amino acid content of red beans is leucine. One of the indicators of good-quality protein is the content of its leucine content is at least $25 \mathrm{mg} / \mathrm{g}$ of protein. 
TABLE II

CHEMICAL ANALYSIS OF INSTANT NOODLES

\begin{tabular}{|c|c|c|c|c|c|}
\hline Treatments & Water(\%) & Ash (\%) & Protein $(\%)$ & Fat $(\%)$ & Carbohydrate (\%) \\
\hline $\mathbf{A}$ & $3,52 \mathrm{a}$ & $0,63 \quad b$ & 7,67 & 12,80 & $75,36 \quad \mathrm{a}$ \\
\hline $\mathbf{B}$ & $2,47 \quad b$ & $0,77 \mathrm{ab}$ & $7,93 \quad \mathrm{c}$ & $14,62 \quad \mathrm{~b} \mathrm{c}$ & $74,19 \quad \mathrm{a}$ \\
\hline $\mathbf{C}$ & $2,37 \quad b$ & $0,83 \mathrm{ab}$ & $8,59 \quad \mathrm{~b} \mathrm{c}$ & $15,34 \mathrm{abc}$ & 73,29 a b \\
\hline D & $2,24 \quad b$ & $1,07 \quad \mathrm{a}$ & $9,36 \mathrm{ab}$ & $17,77 \mathrm{a} \mathrm{b}$ & $69,95 \quad b c$ \\
\hline $\mathbf{E}$ & $1,95 \quad b$ & 1,09 a & $9,76 \mathrm{a}$ & $18,83 \mathrm{a}$ & 68,38 \\
\hline KK & 10,10 & 14,37 & 4,92 & 9,63 & 2,16 \\
\hline
\end{tabular}

\section{F. Fat Content}

The higher the addition of red beans flour, the higher the fat content of the resulting noodles. This is due to the fat content of red beans flour used that was $1.79 \%$. According to Astawan (2009) [8], the fat content in red beans is relatively low, i.e. $1.5 \mathrm{~g} / 100 \mathrm{~g}$ of material. The fat component of red beans consists of $19 \%$ of saturated fatty acids and $63.3 \%$ of unsaturated fatty acids. Most of the saturated fatty acid is in palmitic acid form whereas the unsaturated fatty acids are in the form of oleic acid, linoleic acid and linolenic acid.

\section{G. Carbohydrate Content}

The carbohydrate content in the resulting instant noodles tended to decrease as the number of red beans flour was added, because of the low carbohydrate content on the red beans flour i.e. equal to $64.24 \%$. The carbohydrate content was known not through analysis but through calculation, by subtracting one hundred percent minus the fat content, the water content, the ash content and the protein content.The calculation is known as by different Carbohydrate that is the determination of carbohydrates on groceries roughly. The higher content of protein, ash, fat and water of the product, the lower the carbohydrate content produced in the product [9].

\section{H. The Yield of Noodles}

The yield of noodles is the ratio between the weights generated by the weight of raw materials used in the manufacture of the noodles. The nature and the characteristics of the flour mixture will relate to the amount of noodles that had been produced. The yield of instant noodles can be seen in Table 3 .

TABLE III

CAlCulation Results of THE GENERATED YiEld OF Instant NoOdles

\begin{tabular}{|l|r|}
\hline Treatments & The Yield of Noodles (\%) \\
\hline A & 73,91 a \\
\hline B & $73,21 \quad$ a b \\
\hline C & $72,36 \quad$ b c \\
\hline D & $71,53 \quad$ c d \\
\hline E & $70,50 \quad$ d \\
\hline KK & 0,75 \\
\hline
\end{tabular}

The figures in the same column followed by the different lowercase letter are significantly different according to the level of 5\% DNMRT.

The yield of the resulting instant noodles tended to decrease with the decrease of the amount of cassava flour and the increase of the amount of red bean flour that were used in the manufacture of instant noodles. This is due to the decrease in the amount of cassava flour which meant the decrease in starch content, whereas starch in cassava flour contains amylopectin which has many functions to form the texture and as the binder on noodles or pasta dough. The lower the content of amylopectin in the noodles, the more the noodles is not formed during the formation of strands of noodles. The cassava starch has a high amylopectin content of approximately $86 \%$ [10].

\section{Organoleptic Test}

Organoleptic test aims to determine the level of the panelists' acceptance on the resulting instant noodles.The results of organoleptic test on the instant noodles can be seen in Figure 1.

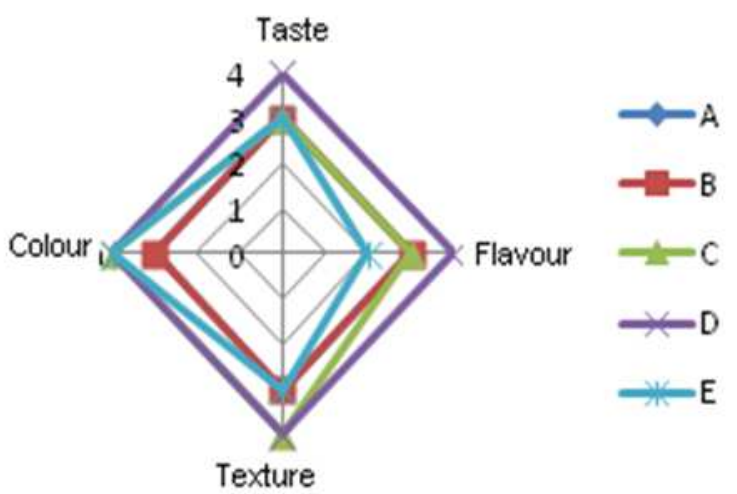

Fig 1. The Organoleptic Test Graph of the Generated Instant Noodles

The flavor compounds in a product can provide stimulation to the senses when the panelists taste it. The presence of glucose, sucrose, starch and others can enhance the flavor of the food. The addition of red beans flour used in the dough will increase the specific flavor of red beans. The typical flavor of kidney beans affects the panelists' acceptance. Flavor is a very important factor in determining the acceptance or the rejection of food by the panelists. If the flafour and the texture of the food are good but it does not taste good, the panelists will reject the production.

The texture of a food depends on the physical state of the material; the assessment of the texture can be the hardness and the crispness. The texture of the product can also be influenced by the content of protein and fat in the ingredients.According to Kusnandar (2010) [7], the oil or fat has an important function in the food processing, i.e. as a heat transfer medium in the frying process, as well as contributing to the formation of the texture and the quality of food products. Based on the color assessment (Figure 1), it can be seen that the panelists preferred the instant noodles on the treatment $\mathrm{C}$ (70 g flour: $22 \mathrm{~g}$ cassava flour + kidney beans flour $8 \mathrm{~g}$ ), D (70 g flour: $20 \mathrm{~g}$ cassava flour + kidney beans flour $10 \mathrm{~g}$ ), and $\mathrm{E}$ (70 $\mathrm{g}$ flour: $18 \mathrm{~g}$ cassava flour + 
kidney beans flour $12 \mathrm{~g}$ ). These noodle products had a yellow color, while the other treatments noodle products were pale yellow.

\section{CONCLUSIONS}

The level of the addition of red beans flour in the manufacture of instant noodles made from wheat flour and cassava flour provided significant effect on the water content, ash content, protein content, fat content, carbohydrate content, and yield. The results of organoleptic test, the product $\mathrm{D}$ ( $70 \mathrm{~g}$ of flour: $20 \mathrm{~g}$ of cassava flour $+10 \mathrm{~g}$ red beans flour) was the preferred product because the panelists chose this product and give the score of 4 in terms of color, flavor, flavour and texture.

The instant noodles with treatment D (70 g of flour: $20 \mathrm{~g}$ of cassava flour $+10 \mathrm{~g}$ of red beans flour) was the best product with the water content $(2.24 \%)$, ash content (1.07\%), protein content $(9.36 \%)$, fat content $(17.77 \%)$, carbohydrate content $(69.95 \%)$, and the yield of noodles $(71.53 \%)$. The instant noodles that met the standards quality of ISO No. 013551-2000 was in treatment C, D and E, with $\geq 8 \%$ of protein content and $\leq 10 \%$ of water content for the noodles that were mixed with frying methods.

\section{REFERENCES}

[1] Marzempi, D. Sastrodipuro, Azman dan Aswardi. 1994. Penggunaan Tepung Ubi Kayu sebagai Bahan Substitusi Terigu dalam Pembuatan Mie. Risalah Seminar Sukarami. Vol. III.

[2] Mahmud, M., Salamet, S.d., Apriyantono, R dan Hermana. 1990. Komposisi Zat Gizi Pangan Indonesia.Jakarta. Depkes RI.

[3] Standar Nasional Indonesia (SNI) nomor 01-3551-2000. Mie Instan. http://sisni.bsn.go.id/index.php?/sni_main/sni/detail_sni/ 3956. [8 April 2011]

[4] Suprapti, M. L. 2002. Tepung Kasava Pembuatan Dan Pemanfaatanya. Yogyakarta. Kanisisus.

[5] Intania, R. 2004. Studi Pembuatan Tepung Kacang Hijau Instan. [Skripsi]. Fakultas Pertanian Universitas Andalas. Padang.

[6] Astawan, Made. 2003. Membuat Mi dan Bihun. Penebar Swadaya. Jakarta.

[7] Kusnandar, F. 2010. Kimia Pangan: Komponen Makro Dian Rakyat. Jakarta.

[8] Astawan, Made. 2009. Sehat dengan Hidangan Kacang dan Bijibijian. Penebar Swadaya. Jakarta.

[9] Winarno, F. G., 2004. Kimia Pangan dan Gizi. Gramedia Pustaka Utama, Jakarta.

[10] Hidayat, B. 2008. Prosiding Seminar Nasional Sains dan Teknologi Pengembangan Formulasi Mie Berbahan Baku Pati Ubi Kayu. Universitas Lampung. Lampung. 